\title{
Fungi Isolated from Different Fruits of Fruit Vendors in Nagpur City
}

\author{
Archana Sawane \\ Department of Botany, S.M. Mohota College of Science, RTM Nagpur University, Nagpur, India \\ amsawane@yahoo.co.in
}

\begin{abstract}
Fruits make important diet for human beings. However, the high concentration of various sugars, minerals, vitamins and amino acids also provide a good platform for the successful growth and survival of various parasitic and saprophytic forms of fungi. Considering the importance of fungi in deterioration of fruits and in causing huge losses, the present study was undertaken to understand different fungi isolated from common fruits available in markets of Nagpur city namely Citrus limon, Citrus sinensis, Pyrus communis, Carissa carandas, Averrhoa carambola, Prunus domestica, Malus domestica and Punica granatum. Fungi were isolated on sterile potato Dextrose Agar and identified on the basis of published literature. Aspergillus niger was having highest frequency of occurrence followed by Fusarium spp. for most of the fruits. Maximum diversity of fungi was seen forCarissa carandas with 8 fungal species followed by Pyrus communis and Prunus domestica with 5 species each. The known potential of isolated species for the mycotoxin production carries significance as contaminated fruits are often consumed in developing countries. Results of the study will help to spread awareness amongst the farmers and those involved in the storage, transport and marketing of the fruits about the need for prevention of storage fungi growth.
\end{abstract}

Keywords: fruits, fungi, mycotoxins, storage

\section{Introduction}

Fruits make important diet for human beings. However, the high concentration of various sugars, minerals, vitamins and amino acids also provide a good platform for the successful growth and survival of various parasitic and saprophytic forms of fungi. Fruits are highly perishable and maintain an active metabolism during the storage phase. During postharvest period diseases can affect the quality of fruits. Postharvest deterioration of fruits may take place in any stages viz. storage, transit or trans-shipment, during handling processes required to move the crop from the grower to the wholesale dealer and to retailer and finally to consumers [1]. For many years, insufficient regard was given to postharvest losses. The emphasis had always been on crop production and the breeding of better varieties. In tropical countries, deterioration tends to be especially rapid because of prevailing high temperature and in many places, high humidity. Physical damage is a very important aspect of post-harvest deterioration and is the primary cause of many losses. Various types of injury can be sustained before, during or after harvest. Causal agents include the weather, insects, birds, rodents and farm implements. Most types of damage cause an increase in respiratory rate and hence a greater heat output. Other adverse effects include increased moisture loss and enhanced production of ethylene. Physical damage very often facilitates invasion by micro-organisms resulting in a progressive decay which may affect the entire organ. Many fruits are resistant to fungal attack when unripe; the infection process is halted almost as soon as it has begun but the fungus remains alive, entering a 'quiescent' or 'latent' phase. The process of ripening is accompanied by a weakening of cell walls and a decline in ability to synthesise antifungal substances, until eventually the fruit is no longer able to resist the advance of the fungus [2].
The internal tissues of fruits are nutrient rich. Their structure is comprised mainly of the polysaccharides cellulose, hemicellulose, and pectin. The principal storage polymer is starch. Spoilage microorganisms exploit the host using extracellular lytic enzymes that degrade these polymers to release water and the plant's other intracellular constituents for use as nutrients for their growth. Fungi in particular produce an abundance of extracellular pectinases and hemicellulases that are important factors for fungal spoilage. The natural acidity of most fruits serves as a barrier to many spoilage microbes, especially bacteria. By contrast, spoilage fungi that typically produce more diverse and greater amounts of extracellular depolymerases successfully attack and spoil both fruits and vegetables [3].

The post-harvest losses of horticultural crops in developing countries have been reported to vary between 15 to 50 percent, with an estimated minimum of 20 percent. Horticultural crops not only provide nutritional and healthy foods, but also generate cash income to growers. Besides their economic importance, fruits play a pivotal role in human diet. In developing countries, inadequate arrangements for post-harvest management like storage, processing, preservation and marketing facilities lead to problem of postharvest losses. After harvesting, most of the farmers transport the fruits to the markets in lorries and tractors. Sometimes while loading in trucks the fruits are directly dumped into lorry without any packing. At the time of unloading the fruits in the wholesale market, the damaged, over ripened, immature and unmarketable size fruits are separated out, resulting into further physical damage [4]

Considering the importance of fungi in deterioration of fruits and in causing huge losses, the present study was undertaken to understand different fungi isolated from common fruits available in markets of Nagpur city. 


\section{Materials and Methods}

Samples of fruits namely Citrus limon(L) Burm(Nimbu), Citrus sinensis(L) Osbeck(Mosambi), Pyrus communis (L) (Nashpati), Carissa carandas(L) (Karanda), Averrhoa carambola(L) (Starfruit, Kamrakh), Prunus domestica(L) (Plum, Alu Bukhar), Malus domestica(Borkh) (apple, Seb) and Punica granatum (Pomegranate, Anar)were collected from fruit vendors of Nagpur. Spoiled or diseased fruits were identified by physical examination and were collected in a sterile polyethylene bags.

Ten fruits of each species were surface sterilized in $1 \%$ hypochlorite for 2 minand then cut into small segments (3 $\mathrm{mm}^{2}$ ) with a sterilized blade and plated on to sterile potato dextrose agar (PDA) in Petri dishes in replicates. The plates were incubated in an inverted position at $26-30^{\circ} \mathrm{C}$ for five days.

The isolated fungi were identified on the basis of macromorphological and micromorphological characteristics. The following morphological characteristics viz. colony growth, presence or absence of aerial mycelium, colony colour, presence of wrinkles and furrows, pigment production etc. were recorded. Microscopic slides were prepared from the fungal growth in the culture media using Lacto-Phenol Cotton Blue as a mounting and staining medium. The micromorphological identification of fungal pathogen was based on the morphology of hyphae, the characteristics of the spores and reproductive structures.Fungal identification was done with the help of published literature [5], [6], [7].

\section{Results and Discussion}

After isolation and identification of different fungi from the culture media, results were tabulated and the same are presented in Table 1 (Relative density with respect to total fungi) and Table 2 (Frequency of occurrence in terms of percentage of fruit samples infected).

Table 1: Relative Density (Percentage Distribution) of different fungi isolated on culture media from different fruits

\begin{tabular}{|c|c|c|c|c|c|c|c|c|}
\hline Species & $\begin{array}{c}\text { Averrhoa } \\
\text { carambola } \\
\text { (Kamrakh) }\end{array}$ & $\begin{array}{c}\text { Carissa } \\
\text { carandas } \\
\text { (Karanda) }\end{array}$ & $\begin{array}{c}\text { Citrus } \\
\text { sinensis } \\
\text { (Mosambi) }\end{array}$ & $\begin{array}{c}\text { Citrus } \\
\text { limon } \\
\text { (Nimbu) }\end{array}$ & $\begin{array}{c}\text { Prunus } \\
\text { domestica } \\
\text { (Alu Bukhar) }\end{array}$ & $\begin{array}{c}\text { Punica } \\
\text { granatum } \\
\text { (Anar) }\end{array}$ & $\begin{array}{c}\text { Pyrus } \\
\text { communis } \\
\text { (Nashpati) }\end{array}$ & $\begin{array}{c}\text { Malus dome- } \\
\text { stica (Seb) }\end{array}$ \\
\hline Alternaria alternata & $43.75(21)$ & $5.26(6)$ & --- & --- & --- & --- & 3.57 & $(3)$ \\
\hline Alternaria solani & --- & $2.63(3)$ & --- & --- & --- & --- & --- & --- \\
\hline Aspergillus flavus & --- & $2.63(3)$ & $4.17(2)$ & $3.13(3)$ & $3.45(2)$ & --- & --- & --- \\
\hline Aspergillus glaucus & ---- & $2.63(3)$ & --- & --- & --- & --- & --- & --- \\
\hline Aspergillus niger & --- & $65.79(75)$ & $41.67(30)$ & $81.25(78)$ & $3.45(2)$ & $76.92(60)$ & $46.43(39)$ & $73.33(33)$ \\
\hline Fusarium spp. & $12.50(6)$ & $13.16(15)$ & $45.83(33)$ & $15.63(15)$ & $17.24(15)$ & $19.23(15)$ & $35.71(30)$ & $20.00(9)$ \\
\hline Memnoniella spp. & --- & --- & --- & --- & $10.34(9)$ & --- & --- & --- \\
\hline Mucor spp. & --- & --- & $4.17(2)$ & --- & --- & --- & --- & $6.67(3)$ \\
\hline Paecilomycesvariotii & ---- & $2.63(3)$ & --- & --- & --- & --- & --- & --- \\
\hline Penicillium spp. & --- & $5.26(6)$ & --- & --- & $65.52(57)$ & $3.85(3)$ & $7.14(6)$ & --- \\
\hline Rhizoctonia solani & $18.75(9)$ & --- & --- & --- & --- & --- & --- & -- \\
\hline Rhizopus & --- & --- & $4.17(3)$ & --- & --- & --- & $7.14(6)$ & --- \\
\hline Stachybotryschartarum & $25.00(12)$ & --- & --- & --- & --- & --- & --- & -- \\
\hline
\end{tabular}

Figures in parentheses indicate number of isolates of different fungal species isolated from all samples of a particular fruit

Maximum fungal isolates were obtained from Carissa carandas, Citrus limonand Prunus domestica. Maximum fungal species (8 species) were isolated from Carissa carandas.

Fusarium spp. was the most frequently isolated fungal species from all the eight fruits studied, followed by Aspergillus niger and Penicillium spp. which were isolated from seven and four different fruits each.

From Pyrus communis, 84 fungal colonies were isolated. Aspergillus niger was the most common fungi isolated. Rhizopus, Fusarium, Alternaria alternata and Penicillium were the other fungi isolated from Pyrus communis.

From Citrus sinensis, 70 fungal colonies were isolated with dominance of Fusarium and A. niger. From Prunus domestica, total 85 isolates were observed out of which maximum isolates were of Penicillium followed by
Fusarium and Neurospora. From Carissa carandas, 114 fungal colonies were isolated with $A$. niger on the top with relative density of $65.79 \%$.

From Averrhoa carambola, total 48 fungal colonies were isolated, out of which Alternaria alternata isolates were maximum; other fungal isolates observed were Stachybotryschartarum, Rhizoctonia solani and Fusarium spp. From Malus domestica, 45 fungal colonies were isolated with dominance of A. niger (73\%); Fusarium and Mucor were the other fungi.

From Punica granatum, total 78 colonies were grown with a dominance of $A$. niger with relative density of $76.9 \%$. Fusarium and Penicillium were the other isolates. From Citrus limon, 96 fungal colonies were isolated, out of which 78 isolates belonged to A. niger(relative density of $81.25 \%$ ) suggesting that it was the most dominant fungal species. 
Table 2: Frequency of Occurrence (Percentage of samples infected) of different fungi on fruit samples

\begin{tabular}{|c|c|c|c|c|c|c|c|c|}
\hline Species & $\begin{array}{l}\text { Averrhoa } \\
\text { carambola } \\
\text { (Kamrakh) }\end{array}$ & $\begin{array}{c}\text { Carissa } \\
\text { carandas } \\
\text { (Karanda) }\end{array}$ & $\begin{array}{c}\text { Citrus } \\
\text { sinensis } \\
\text { (Mosambi) }\end{array}$ & $\begin{array}{c}\text { Citrus } \\
\text { limon } \\
(\mathrm{Nimbu})\end{array}$ & $\begin{array}{c}\text { Prunus } \\
\text { domestica } \\
\text { (Alu Bukhar) }\end{array}$ & $\begin{array}{c}\text { Punica } \\
\text { granatum } \\
\text { (Anar) }\end{array}$ & $\begin{array}{c}\text { Pyrus } \\
\text { communis } \\
\text { (Nashpati) }\end{array}$ & $\begin{array}{c}\text { Malus } \\
\text { dome-stica } \\
\text { (Seb) }\end{array}$ \\
\hline Alternaria alternata & 50 & 10 & --- & --- & --- & --- & 10 & $\begin{array}{ll}-- \\
--\end{array}$ \\
\hline Alternaria solani & --- & 10 & --- & --- & --- & --- & --- & --- \\
\hline Aspergillus flavus & --- & 10 & 10 & 10 & 10 & --- & --- & --- \\
\hline Aspergillus glaucus & --- & 10 & --- & --- & --- & --- & --- & --- \\
\hline Aspergillus niger & --- & 90 & 60 & 90 & 10 & 80 & 80 & 60 \\
\hline Fusarium spp. & 10 & 30 & 70 & 40 & 40 & 40 & 60 & 20 \\
\hline Memnoniella spp. & --- & --- & --- & --- & 20 & --- & --- & --- \\
\hline Mucor spp. & --- & --- & 10 & --- & --- & --- & --- & 10 \\
\hline Paecilomycesvariotii & --- & 10 & --- & --- & --- & --- & --- & --- \\
\hline Penicillium spp. & --- & 20 & --- & --- & 90 & 10 & 20 & --- \\
\hline Rhizoctonia solani & 20 & --- & --- & --- & --- & --- & --- & --- \\
\hline Rhizopus & --- & --- & 10 & --- & --- & --- & 20 & --- \\
\hline Stachybotryschartarum & 30 & --- & --- & --- & --- & --- & --- & --- \\
\hline
\end{tabular}

From the results, it can be observed that most frequently isolated fungi are the Aspergillus, Fusarium, Penicillium and Rhizopus with the dominance of A. niger.

Postharvest rot diseases of some stone fruits (apricots, cherries, peaches and plums) collected from Jeddah City, Saudi Arabia were evaluated by Hawazen et al. [8].The highest percentage of infection was recorded in fruits with street sellers and the smallest one was recorded in cold storage cars. Mycoflora of the apparently healthy fruits included Alternaria, Aspergillus, Diplodia, Fusarium, Monilinia, Penicillium, Rhizopus, Stemphylium and Thamnidium. The mycoflora of rotted fruits did not differ from healthy fruits, but the total counts of dominant species were different. Rhizopus stolonifer, Penicillium expansum, Aspergillus niger and Moniliniafructicola were the most dominant species.

Gualandizzi et al., (2001) indicated that M. laxa, R. stolonifer and $B$. cinerea were more common on the fruits of plum, peach, apricot before and after harvest [9]. About 39 fungal isolate belonging to 16 genera of fungi were recorded on post-harvest decay apple, orange, banana, mango and grape fruits in Sana'a market, Yemen [10].

Bukar, et al. [11] carried out mycological studies on fungi in apparently diseased sweet oranges (Citrus sinensis) sampled from retailers at Na'ibawa Yan Lemu market in Kano Metropolis. The most predominant pathogenic fungus isolated from the samples was, Aspergillussp (32.5\%); others include Mucor spp. (25\%), Penicillium spp. (15\%), Rhizopus spp. (15\%), Fusarium spp. (7.5\%), and Alternariaspp (5\%).

C. L. Xiao and J. D. Rogers isolated Sphaeropsispyriputrescens from the decayed fruit of Pyrus [12].Lennox and Spotts (2003) studied the diseases of pear fruits and observed that Botrytis cinerea caused 55\% of the total decay, while Penicillium spp. and Mucor piriformis were responsible for 24 and $8 \%$ decay, respectively. The remaining $13 \%$ was ascribed to other pathogens, including Alternaria and Pezicula spp. [13].

Rashad R. Al-Hindi et al. have done investigations on isolation and identification of some fruit spoilage fungi in Jeddah city, Kingdom of Saudi Arabia in 2011 and isolated different fungi from twelve types of various fruits, banana, orange, lemon, tomato, peach, apple, grape, date, mango, pokhara, apricot and kiwi [14]. Ten fruit spoilage fungi were isolated and identified as follows Fusarium oxysporum (banana and grape), Aspergillus japonicus (pokhara and apricot), Aspergillus oryzae (orange), Aspergillus awamori (lemon), Aspergillus phoenicis (tomato), Aspergillustubingensis (peach), Aspergillus niger (apple), Aspergillus flavus (mango), Aspergillus foetidus (kiwi) and Rhizopus stolonifer (date).

An investigation was carried by BenkeeThiyam and G.D. Sharma [1] in 2013 to study the fungal diseases of eight selected local fruits in Cachar district, Assam and twentythree fungal pathogens were isolated which caused spoilage of fruits. Aspergillus was commonest fungus found in all fruits during storage of fruits. Other genera like Acremonium, Alternaria, Aspergillus, Chalaropsis, Cladosporium, Curvularia, Fusarium, Mucor, Penicillium, Rhizopus, and Trichoderma were common in fruits stored in warm and humid condition.

Patel [15] reported that the species Aspergillus niger, Rhizopus arrhizusand Penicillium digitatum are responsible for most of the decay of apples in Ahmedabad market.

Post-harvest fungal diseases of fruits and vegetables were also studied in Nagpur by Rinkey, et al. in 2014 [16]. Fungal diseases of 17 selectable fruits and vegetables were studied and their fungal pathogen were observed. Amongst these were Aspergillus, Alternaria sp., Fusarium sp., Mucor sp., Penicillium sp. and Rhizopussp found to be major diseasecausing organism.

Fungal infection of the fruits by storage fungi is harmful because of the mycotoxins produced by different fungal species. Aflatoxin B1, B2 and to some extent Aflatoxin G1 and G2, Ochratoxin A, Patulin, Citrinin. Alternariol, Alternariol methyl ether, Tenuazonic acid, Zearalenol, Fumonisin B have been reported to be present in these fruits by various researchers [7], [17], [18].

The known potential of these species for the mycotoxin production carries significance as contaminated fruits are often consumed in developing countries. These mycotoxins have a broad spectrum of toxicity including mutagenicity, teratogenicity and carcinogenicity [7]. Thus, there is a need 
to use more antifungal measures to decrease the fungal contamination of the stored fruits.

\section{Conclusion}

Conclusively, the results of the present study have revealed that the spoiled fruits were mainly contaminated with Aspergillus, Fusarium, Penicillium, Rhizopus and Alternaria. Fruits were observed to have been contaminated with more than one fungal organism. Presence of these fungi on fruits, especially Aspergillus spp. poses a serious threat to health of consumers as the organism could produce mycotoxins, which are lethal when consumed. Most of the fungi isolated are able to reinfect healthy fruits within short time, which poses a serious economic threat to sellers of fruits in the market.

Proper handling from the farm as well as during storage and the avoidance of mixing of diseased ones with the healthy ones are important factors in preventing loss. The use of suitable treatment of the fruits can also be one of the means of reducing economic loss due to fungal pathogens.

Results of the study will help to spread awareness amongst the farmers and those involved in the storage, transport and marketing of the fruits about the need for prevention of storage fungi growth.

\section{Acknowledgements}

Author is thankful to Dr. A.A. Fulzele, Head, Department of Botany, S.M. Mohota College of Science, Nagpur for his immense help in identification of fungi.

\section{References}

[1] B. Thiyamand G.D. Sharma."Isolation and Identification of Fungi Associated with Local Fruits of Barak Valley, Assam," Current World Environment, 8(2), pp. 319-322, 2013.

[2] A.L. Snowdon. "A colour atlas of post-harvest diseases and disorders of fruits and vegetables," Vol I: General Introduction and fruits. University of Cambridge. Published by Wolfe Scientific Ltd., 1990.

[3] Barth Margaret, R. Thomas, Hankinson, Hong Zhuang, and Frederick Breidt."Microbiological Spoilage of Fruits and Vegetables"

[4] Moula Sab, M.B. Ashok and S.N. Sudhakara."Estimation of Post-Harvest Losses of Mangoes at Different Stages from Harvesting to Consumption," Int.J.Curr.Microbiol.App.Sci 6(12), pp. 310-318, 2017.

[5] C.J. Alexopoulos."Introductory Mycology," John Wiley and Sons, Inc., New York pp: 229-30, 1961.

[6] B.S. Malik, “A Laboratory Manual of Veterinary Microbiology, Part III. Pathogenic Bacteriology and Mycology," 4th Ed., pp: 137-46, 1996.

[7] Singh, K.; Frisvad, J.C.; Thrane, U.; and Mathur, S.B. (1991) An illustrated Manual on Identification of some Seed-borne Aspergilli, Fusaria, Penicillia and their Mycotoxins. Dan. Gov. Inst. Seed Pathol., Tech. Bull., $133 \mathrm{pg}$.
[8] H.K. Hawazen, Lubna S. Nawar and F. H. Tawfiq, "Postharvest Rot Diseases of Some Stone Fruits Collected From Jeddah City, Saudi Arabia," IOSR Journal of Pharmacy and Biological Sciences (IOSRJPBS) 12, pp.29-37, 2017.

[9] S. Gualandizzi, A. Folchi, M.M.F. Neri, S.Brigati, and G.C. Pratella."Quality peach from the southRivista," di Frutticoltura, e. di, Ortofloricoltura, 63 (10),pp. 47-52, 2001.

[10] Q. Abdullah, A. Mahmoud, A. Al-harethi. "Isolation and identification of fungal post-harvest rot of some fruits in Yemen," PSM Microbiol, 01(1), pp. 36-44, 2016.

[11] A. Bukar, M.D. Mukhtar, and S. Adamu."Isolation and Identification of Postharvest Spoilage Fungi Associated With Sweet Oranges (Citrus Sinensis) Traded In Kano metropolis,"Bayero Journal of Pure and Applied Sciences, 2(1), pp. 122 - 124, 2009.

[12] C. L. Xiao, J. D. Rogers."A Postharvest Fruit Rot in d'Anjou Pears Caused by Sphaeropsispyriputrescens sp.," Plant Disease, 88(2), pp.114-118, 2004. DOI: 10.1094/PDIS.2004.88.2.114

[13] C.L. Lennox, R.A. Spotts."Sensitivity of populations of Botrytis cinerea from pear-related sources to benzimidazole and dicarboximide fungicides," Plant Disease, 87(6), pp. 645-649, 2003.

[14] R. Rashad, R. Ahmed, and A. M. Saleh. "Isolation and identification of some fruit spoilage fungi: Screening of plant cell wall degrading enzymes," African Journal of Microbiology Research, 5(4), pp. 443-448, 2011.

[15] R.B. Patel."Post-harvest disease of apple fruits and control,” Indian J. Microbiol., 24(2),pp.142-143, 1984.

[16] P. Rinkey, U. Thakur and N. Dongarwar."Post-harvest fungal diseases of fruits and vegetables in Nagpur," Int. J. of Life Sciences, Special Issue A2,pp. 56-58, 2014.

[17] S. Drusch S and J. Aumann. "Mycotoxins in fruits: Microbiology, Occurrence, and changes during Fruit processing," Advances in Food and Nutrition Research, 50, pp. 33-78, 2005. ISSN: 1043-4526. DOI: 10.1016/S1043-4526(05)50002-0.

[18] A. Sawane and A. Saoji. "Airborne Penicillium in fruit markets: One of the post-harvest decay agents," Indian Journal of Aerobiology, 17 (\&2), pp. 25-31, 2004.

\section{Author Profile}

Archana Sawane is currently working as Associate Professor in Department of Botany at S. M. Mohota College of Science, Nagpur. She graduated from Shivaji Science College, Nagpur and obtained her post-graduation and doctoral degree in Botany from Government Institute of Science, Nagpur.Her areas of research are Aerobiology, Mycology and Palynology. 